\title{
Associations between glucokinase and glucokinase regulatory protein gene polymorphisms and clinical parameters in pregnant women
}

\section{Związek pomiędzy polimorfizmami genu glukokinazy i białka regulatorowego glukokinazy a parametrami klinicznymi u kobiet w ciąży}

\author{
Alicja Wieczorek¹, Krzysztof Safranow², Maciej Tarnowski³ ${ }^{3}$ Andrzej Pawlik³ ${ }^{3}$ Violetta Dziedziejko²凶 \\ ${ }^{1}$ Centrum Medyczne „For-Dent”, ul. Bogusława 10, 74-200 Pyrzyce \\ Medical Center "For-Dent" \\ ${ }^{2}$ Pomorski Uniwersytet Medyczny w Szczecinie, Katedra Biochemii i Chemii Medycznej, al. Powstańców Wlkp. 72, 70-111 Szczecin \\ Pomeranian Medical University in Szczecin, Department of Biochemistry and Medical Chemistry \\ ${ }^{3}$ Pomorski Uniwersytet Medyczny w Szczecinie, Katedra Fizjologii, al. Powstańców Wlkp. 72, 70-111 Szczecin \\ Pomeranian Medical University in Szczecin, Department of Physiology \\ $\triangle$ viola@pum.edu.pl
}

\begin{abstract}
Introduction: Glucose is the main energy substrate for intrauterine growth. Changes in the metabolism of carbohydrates, the predominant dietary source of glucose, may adversely influence the foetus, for example resulting in large for gestational age infants. The uptake and storage of glucose is regulated by glucokinase (GCK), an enzyme modulated by the glucokinase regulatory protein (GCKR), which catalyses hepatic phosphorylation of glucose, leading to the synthesis of glycogen and triacylglycerols.

As the polymorphisms GCK rs1799884 and GCKR rs780094 have been implicated in dyslipidaemia and diabetes mellitus type 2 in pregnancy, the aim of this study was to examine the associations between these polymorphisms and clinical parameters in pregnant women.
\end{abstract}

Materials and methods: This study included 207 pregnant women with normal values of oral glucose tolerance test (OGTT). We analysed associations between the studied polymorphisms and clinical parameters, such as body mass before pregnancy, body mass at delivery, body mass increase during pregnancy, body mass index (BMI) before pregnancy, BMI at delivery, BMI increase during pregnancy, gestational age at delivery, newborn body mass, APGAR score and glucose concentrations in OGTT. Results and conclusion: There were no statistically significant associations between the GCK rs1799884 and GCKR rs780094 polymorphisms and the studied clinical parameters apart from a higher BMI increase during pregnancy in women with the GCK rs1799884 CC genotype.

Keywords: carbohydrate metabolism; polymorphism; pregnancy.

Materiały i metody: Do badania włączono 207 kobiet w ciąży z prawidłowymi wartościami doustnego testu tolerancji glukozy (OGTT). Przeanalizowano związek między badanymi polimorfizmami a parametrami klinicznymi takimi jak: masa ciała przed ciążą, masa ciała przy porodzie, wzrost masy ciała w czasie ciąży, wskaźnik masy ciała (BMI) przed ciążą, BMI przy porodzie, wzrost BMI w trakcie ciąży, czas trwania ciąży, masa ciała noworodka, wynik w skali APGAR i stężenia glukozy dla OGTT. Wyniki i wnioski: Nie stwierdzono zależności istotnych statystycznie między polimorfizmami GCK rs1799884 i GCKR rs780094 a badanymi parametrami klinicznymi, z wyjątkiem wyższego wzrostu BMI podczas ciąży u kobiet z genotypem CC GCK rs1799884.

Słowa kluczowe: metabolizm węglowodanów; polimorfizm; ciąża.

\section{INTRODUCTION}

Intrauterine growth and development are associated with maternal, environmental, and genetic factors. The primary maternal factor that regulates feto-placental growth is substrate delivery to the placental site, with glucose being the main energy substrate [1]. Changes in the metabolism of carbohydrates, the predominant dietary source of glucose, may adversely influence the foetus, for example resulting in large for gestational age (LGA) infants [2]. In particular, LGA babies are predisposed to a variety of adverse obstetric and neonatal outcomes, and delivery of a large infant significantly increases 
the risk of birth complications for the mother [3, 4]. In the long term, infants who are at the highest end of the distribution for weight or body mass index (BMI) are more likely to be obese in childhood, adolescence, and early adulthood than other infants, and are at risk of cardiovascular and metabolic complications later in life $[5,6]$.

Glucokinase (GCK) is the enzyme responsible for regulating the uptake and storage of glucose [7]. The glucokinase regulatory protein (GCKR) modulates glucokinase, which catalyses hepatic phosphorylation of glucose, leading to the synthesis of glycogen and triacylglycerols. Variants in GCKR are associated with effects on fasting glucose and triacylglycerols [8]. The GCKR rs780094 and GCK rs1799884 polymorphisms have been reported to be associated with dyslipidaemia and diabetes mellitus type 2 [9].

The aim of this study was to examine the associations between GCK rs1799884 and GCKR rs780094 polymorphisms and clinical parameters in pregnant women.

\section{MATERIALS AND METHODS}

\section{Patients}

This study included 207 pregnant women with normal values of oral glucose tolerance test (OGTT) of a $75 \mathrm{~g}$ oral glucose tolerance test at 24-28 weeks gestation. All pregnant women were without any acute and chronic complications, such as diabetic ketoacidosis or other disorders affecting glucose metabolism.

\section{Methods}

All samples were genotyped in duplicate using allelic discrimination assays with TaqMan $\AA$ probes (Applied Biosystems, Carlsbad, California, USA) on a CFX96 Touch $^{\text {TM }}$ Real-Time PCR Detection System (Bio-Rad, Hercules, California, USA). To discriminate the GCK and GCKR gene polymorphisms, TaqMan ${ }^{\circledR}$ Pre-Designed SNP Genotyping Assays were used (assay IDs: C_8304645_10 and C__2862873_10), including appropriate primers and fluorescently labelled (FAM and VIC) MGB $^{\text {TM }}$ probes to detect the alleles. Genotypes were assigned using all of the data from the study simultaneously.

\section{Statistical analysis}

The consistency of the genotype distribution with HardyWeinberg equilibrium (HWE) was assessed using the exact test. Clinical parameters were compared between genotype groups using a Mann-Whitney U test. Differences at $\mathrm{p}<0.05$ were considered statistically significant.

\section{RESULTS}

The distributions of the studied genotypes were in HWE $(p<0.05)$. We analysed associations between the studied polymorphisms and clinical parameters such as: body mass before pregnancy, body mass at delivery, body mass increase during pregnancy, BMI before pregnancy, BMI at delivery, BMI increase during pregnancy, gestational age at delivery, newborn body mass, APGAR score, and glucose concentrations in OGTT.

As shown in Tables 1 and 2 there were no statistically significant associations between GCK rs1799884 and GCKR rs780094 polymorphisms and the studied clinical parameters except higher BMI increase during pregnancy in women with the GCK rs1799884 CC genotype (Tables 1 and 2).

TABLE 1. Clinical parameters of pregnant women according to GCK rs1799884 genotype

\begin{tabular}{|c|c|c|c|}
\hline \multirow{3}{*}{ Parameters } & \multicolumn{3}{|c|}{ GCK rs1799884 genotype } \\
\hline & $\begin{array}{c}C C \\
n=163\end{array}$ & $\begin{array}{c}C T+T T \\
n=42+2\end{array}$ & $\begin{array}{c}\text { CC } \\
\text { vs CT + TT }\end{array}$ \\
\hline & \multicolumn{2}{|c|}{ mean $\pm S D$} & $p^{*}$ \\
\hline $\begin{array}{l}\text { Body mass before pregnancy } \\
(\mathrm{kg})\end{array}$ & $62.8 \pm 12.3$ & $64.8 \pm 12.7$ & 0.26 \\
\hline Body mass at delivery (kg) & $78.0 \pm 14.6$ & $78.5 \pm 12.8$ & 0.48 \\
\hline $\begin{array}{l}\text { Body mass increase during } \\
\text { pregnancy }(\mathrm{kg})\end{array}$ & $15.1 \pm 5.7$ & $13.7 \pm 4.2$ & 0.10 \\
\hline $\begin{array}{l}\text { BMI before pregnancy } \\
\left(\mathrm{kg} / \mathrm{m}^{2}\right)\end{array}$ & $23.0 \pm 4.1$ & $23.3 \pm 3.7$ & 0.52 \\
\hline BMI at delivery $\left(\mathrm{kg} / \mathrm{m}^{2}\right)$ & $28.5 \pm 4.8$ & $28.2 \pm 3.6$ & 0.88 \\
\hline $\begin{array}{l}\text { BMI increase during } \\
\text { pregnancy }\left(\mathrm{kg} / \mathrm{m}^{2}\right)\end{array}$ & $5.5 \pm 2.0$ & $4.9 \pm 1.5$ & 0.059 \\
\hline $\begin{array}{l}\text { Gestational age at delivery } \\
\text { (weeks) }\end{array}$ & $39.0 \pm 1.6$ & $39.4 \pm 1.4$ & 0.25 \\
\hline Birthweight (g) & $3338 \pm 533$ & $3448 \pm 515$ & 0.21 \\
\hline $\operatorname{APGAR}(0-10)$ & $9.9 \pm 0.4$ & $10.0 \pm 0.2$ & 0.63 \\
\hline OGTT $0 \mathrm{~h}(\mathrm{mg} / \mathrm{dL})$ & $76.0 \pm 8.9$ & $75.4 \pm 8.2$ & 0.56 \\
\hline OGTT 2 h (mg/dL) & $101.7 \pm 20.3$ & $95.8 \pm 21.8$ & 0.077 \\
\hline
\end{tabular}

BMI - body mass index; OGTT - oral glucose tolerance test; * Mann-Whitney U test

\section{DISCUSSION}

In this study we examined associations between the $G C K$ rs1799884 and GCKR rs780094 polymorphisms and selected clinical parameters in pregnant women. There were no statistically significant associations between the studied polymorphisms and clinical parameters in the pregnant women and newborns, apart from a higher BMI increase during pregnancy in women with the GCK rs1799884 CC genotype.

Glucokinase regulates glucose storage and disposal in the liver for maintaining blood glucose homeostasis. In the pancreatic $\beta$-cells, GCK controls insulin secretion and biosynthesis [I0]. In the liver, GCK regulates glycogen synthesis and gluconeogenesis, and its activity is competitively inhibited by GCKR [11]. Glucokinase is a key regulator of glucose disposal and storage in both liver and pancreatic beta-cells, and responds to increases in circulating glucose concentration by initiating a signalling cascade that results in insulin secretion from the beta-cells and subsequent hepatic glucose uptake and storage $[12,13]$.

Glucokinase regulatory protein is associated with several metabolic pathways [14]. In the liver, GCKR forms an inhibitory complex with GCK, the enzyme responsible for regulating the uptake and storage of dietary glucose [15]. The glucokinase 
TABLE 2. Clinical parameters of pregnant women according to GCKR rs780094 genotype

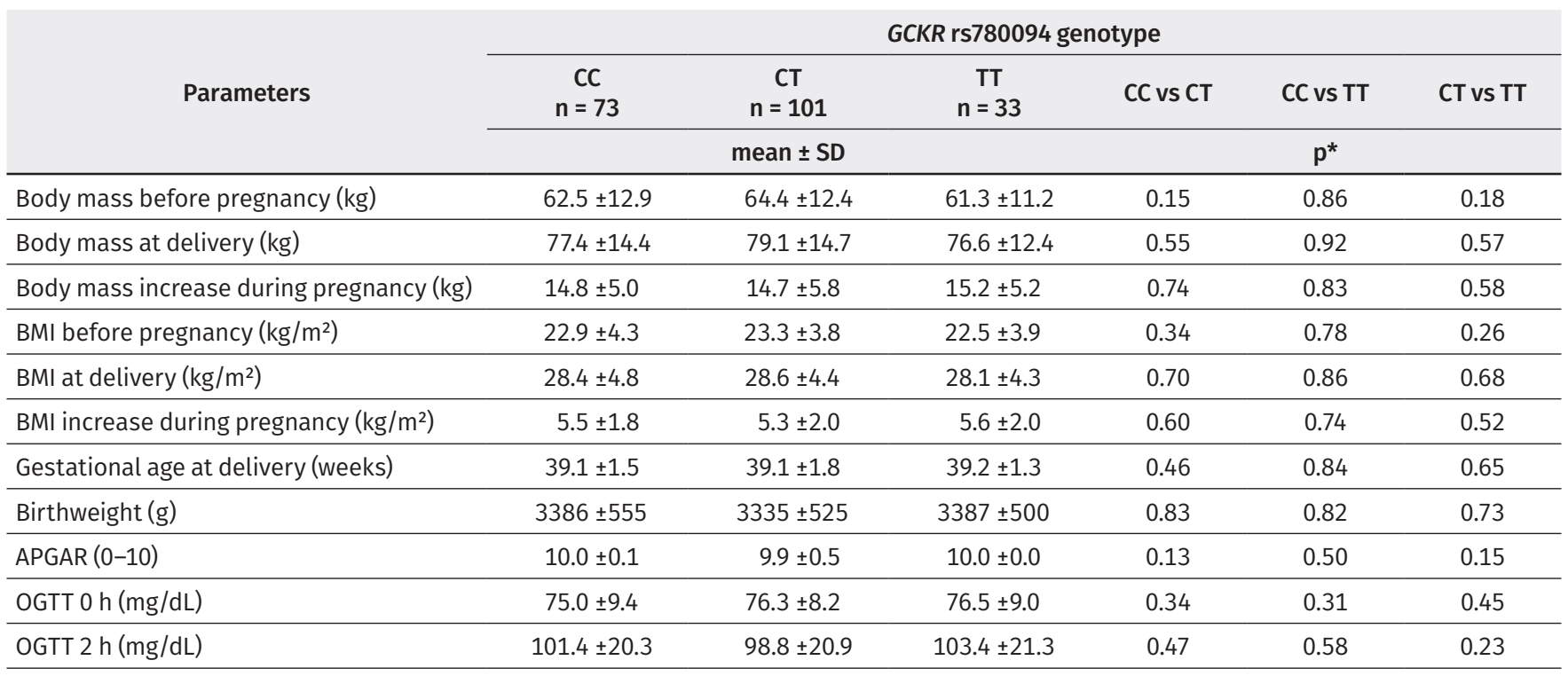

$\mathrm{BMI}$ - body mass index; OGTT - oral glucose tolerance test; * Mann-Whitney U test

regulatory protein regulates hepatic GCK activity competitively with respect to the substrate glucose, the phosphate esters fructose 6- and fructose 1-phosphate, which enhance or inhibit the action of the regulatory protein, respectively $[16,17]$.

Previous studies have shown that glucokinase and glucokinase regulatory protein play important roles in carbohydrate and lipid metabolism, therefore may influence body mass, result in the development of obesity as well as diabetes type 2 and gestational diabetes (GDM) [18].

Hu et al. have shown that polymorphisms in the GCK gene modulated fasting glucose levels in the normoglycaemic population, and were associated with type 2 diabetes. Moreover, they found that GCK genetic variants were associated with insulin secretion [19].

Common GCK gene variants are associated with elevated fasting glucose levels and impaired insulin secretion, suggesting that these polymorphisms may enhance hyperglycaemia in predisposed individuals [20]. Han et al. suggested that the GCK rs1799884 polymorphism may be associated with the susceptibility to GDM in the Chinese population [21].

The polymorphism rs780094, located in the intron of GCKR, has been established as a contributor to various metabolic and lipid parameters. GCKR rs780094 polymorphism is associated with the risk of type 2 diabetes and dyslipidaemia in Chinese individuals. In addition, the authors indicated that the effect on type 2 diabetes is probably mediated through impaired beta cell function [22].

Two studies suggest an association between GCKR rs780094 and GDM. Stuebe et al. have found an association between GDM and carrier status of the GCKR rs780094 C allele [23]. In a study by Huopio et al., there was an association between the GCKR rs780094 C allele and GDM [24].

The liver is responsible for the metabolism of dietary glucose, and responds to periods of hypoglycaemia by initiating gluconeogenic and glycogenolytic pathways designed to maintain blood glucose concentrations at homeostatic levels [25].
Adaptations in maternal carbohydrate metabolism are particularly important in pregnancy because glucose is the principal energy substrate used by the foetus [26]. Glucose metabolism is affected by genes encoding glucoregulatory enzymes such as glucokinase and glucokinase regulatory protein.

\section{CONCLUSION}

The results of our study suggest that polymorphisms in the genes encoding glucokinase and glucokinase regulatory protein do not have a significant effect on the selected clinical parameters in pregnant women, although GCK rs1799884 polymorphism may influence BMI increase during pregnancy.

\section{REFERENCES}

1. Bao W, Li S, Chavarro JE, Tobias DK, Zhu Y, Hu FB, et al. Low carbohydratediet scores and long-term risk of type 2 diabetes among women with a history of gestational diabetes mellitus: a prospective cohort study. Diabetes Care 2016;39(1):43-9. doi: 10.2337/dc15-1642.

2. Pang WW, Colega M, Cai S, Chan YH, Padmapriya N, Chen LW, et al. Higher maternal dietary protein intake is associated with a higher risk of gestational diabetes mellitus in a multi-ethnic Asian cohort. J Nutr 2017;147(4):653-60. doi: 10.3945/jn.116.243881.

3. Hoirisch-Clapauch S, Porto MA, Nardi AE. May maternal lifestyle have an impact on neonatal glucose levels? Med Hypotheses 2016;87:80-6. doi: 10.1016/j.mehy.2015.11.017.

4. Donnelly JM, Walsh JM, Byrne J, Molloy EJ, McAuliffe FM. Impact of maternal diet on neonatal anthropometry: a randomized controlled trial. Pediatr Obes 2015;10(1):52-6. doi: 10.1111/j.2047-6310.2013.00216.x.

5. Ahlsson F, Diderholm B, Jonsson B, Nordén-Lindberg S, Olsson R, Ewald $U$, et al. Insulin resistance, a link betweenvmaternal overweight and fetal macrosomia in nondiabetic pregnancies. Horm Res Paediatr 2010;74(4):267-74. doi: 10.1159/000295710.

6. Zheng J, Zhang Q, Mul JD, Yu M, Xu J, Qi C, et al. Maternal high-calorie diet is associated with altered hepatic microRNA expression and impaired metabolic health in offspring at weaning age. Endocrine 2016;54(1):7080. doi: 10.1007/s12020-016-0959-9. 
7. Markwardt ML, Seckinger KM, Rizzo MA. Regulation of glucokinase by intracellular calcium levels in pancreatic $\beta$ cells. J Biol Chem 2016;291(6):3000-9. doi: 10.1074/jbc.M115.692160.

8. Mohás M, Kisfali P, Járomi L, Maász A, Fehér E, Csöngei V, et al. GCKR gene functional variants in type 2 diabetes and metabolic syndrome: do the rare variants associate with increased carotid intima-media thickness? Cardiovasc Diabetol 2010;9:79. doi: 10.1186/1475-2840-9-79.

9. Hishida A, Morita E, Naito M, Okada R, Wakai K, Matsuo K, et al. Associations of apolipoprotein A5 (APOA5), glucokinase (GCK) and glucokinase regulatory protein (GCKR) polymorphisms and lifestyle factors with the risk of dyslipidemia and dysglycemia in Japanese - a cross-sectional data from the J-MICC Study. Endocr J 2012;59(7):589-99.

10. Fu D, Cong X, Ma Y, Cai H, Cai M, Li D, et al. Genetic polymorphism of glucokinase on the risk of type 2 diabetes and impaired glucose regulation: evidence based on 298,468 subjects. PLoS One 2013;8(2):e55727. doi: 10.1371/journal.pone.0055727.

11. Sparsø T, Andersen G, Nielsen T, Burgdorf KS, Gjesing AP, Nielsen AL, et al. The GCKR rs780094 polymorphism is associated with elevated fasting serum triacylglycerol, reduced fasting and OGTT-related insulinaemia, and reduced risk of type 2 diabetes. Diabetologia 2008;51(1):70-5. doi: 10.1007/s00125-007-0865-z.

12. Agius L. Hormonal and metabolite regulation of hepatic glucokinase. Annu Rev Nutr 2016;36:389-415. doi: 10.1146/annurev-nutr-071715-051145.

13. Haeusler RA, Camastra S, Astiarraga B, Nannipieri M, Anselmino M, Ferrannini E. Decreased expression of hepatic glucokinase in type 2 diabetes. Mol Metab 2014;4(3):222-6. doi: 10.1016/j.molmet.2014.12.007.

14. Beer NL, Tribble ND, McCulloch LJ, Roos C, Johnson PR, Orho-Melander M, et al. The P446L variant in GCKR associated with fasting plasma glucose and triglyceride levels exerts its effect through increased glucokinase activity in liver. Hum Mol Genet 2009;18(21):4081-8. doi: 10.1093/hmg/ ddp357.

15. Cullen KS, Al-Oanzi ZH, O’Harte FP, Agius L, Arden C. Glucagon induces translocation of glucokinase from the cytoplasm to the nucleus of hepatocytes by transfer between 6-phosphofructo 2-kinase/fructose 2,6-bisphosphatase- 2 and the glucokinase regulatory protein. Biochim Biophys Acta 2014;1843(6):1123-34. doi: 10.1016/j.bbamcr.2014.02.006.

16. Rees MG, Wincovitch S, Schultz J, Waterstradt R, Beer NL, Baltrusch S, et al. Cellular characterisation of the GCKR P446L variant associated with type 2 diabetes risk. Diabetologia 2012;55(1):114-22. doi: 10.1007/ s00125-011-2348-5.

17. Park JM, Kim TH, Jo SH, Kim MY, Ahn YH. Acetylation of glucokinase regulatory protein decreases glucose metabolism by suppressing glucokinase activity. Sci Rep 2015;5:17395. doi: 10.1038/srep17395.

18. Li X, Shu YH, Xiang AH, Trigo E, Kuusisto J, Hartiala J, et al. Additive effects of genetic variation in GCK and G6PC2 on insulin secretion and fasting glucose. Diabetes 2009;58(12):2946-53. doi: 10.2337/db09-0228.

19. Hu C, Zhang R, Wang C, Yu W, Lu J, Ma X, et al. Effects of GCK, GCKR, G6PC2 and MTNR1B variants on glucose metabolism and insulin secretion. PLoS One 2010;5(7):e11761. doi: 10.1371/journal.pone.0011761.

20. Tam CH, Ho JS, Wang Y, Lee HM, Lam VK, Germer S, et al. Common polymorphisms in MTNR1B, G6PC2 and GCK are associated with increased fasting plasma glucose and impaired beta-cell function in Chinese subjects. PLoS One 2010;5(7):e11428. doi: 10.1371/journal.pone.0011428.

21. Han X, Cui H, Chen X, Xie W, Chang Y. Association of the glucokinase gene promoter polymorphism -30G > A (rs1799884) with gestational diabetes mellitus susceptibility: a case-control study and meta-analysis. Arch Gynecol Obstet 2015;292(2):291-8. doi: 10.1007/s00404-015-3635-z.

22. Qi Q, Wu Y, Li H, Loos RJ, Hu FB, Sun L, et al. Association of GCKR rs780094, alone or in combination with GCK rs1799884, with type 2 diabetes and related traits in a Han Chinese population. Diabetologia 2009;52(5):83443. doi: 10.1007/s00125-009-1290-2.

23. Stuebe AM, Wise A, Nguyen T, Herring A, North KE, Siega-Riz AM. Maternal genotype and gestational diabetes. Am J Perinatol 2014;31(1):69-76. doi: $10.1055 / \mathrm{s}-0033-1334451$.

24. Huopio H, Cederberg H, Vangipurapu J, Hakkarainen H, Pääkkönen M, Kuulasmaa T, et al. Association of risk variants for type 2 diabetes and hyperglycemia with gestational diabetes. Eur J Endocrinol 2013;169(3):291-7. doi: 10.1530/EJE-13-0286.

25. Zheng J, Xiao X, Zhang Q, Yu M, Xu J, Wang Z. Maternal protein restriction induces early-onset glucose intolerance and alters hepatic genes expression in the peroxisome proliferator-activated receptor pathway in offspring. J Diabetes Investig 2015;6(3):269-79. doi: 10.1111/jdi.12303.

26. Walsh JM, Mahony RM, Canty G, Foley ME, McAuliffe FM. Identification of those most likely to benefit from a low-glycaemic index dietary intervention in pregnancy. Br J Nutr 2014;112(4):583-9. doi: 10.1017/ S000711451400110X. 